\title{
Excavation of an urned cremation burial of the Bronze Age, Glennan, Argyll and Bute
}

\author{
by Gavin MacGregor \\ GUARD, Gregory Building, Lilybank Gardens, \\ University of Glasgow, Glasgow G12 8QQ \\ with contributions from \\ Michael Donnelly, Jennifer Miller and Julie Roberts \\ illustrations by Gary Tompsett and Caitlin Evans
}

Scottish Archaeological Internet Report 8, 2003

www.sair.org.uk 
Published by the Society of Antiquaries of Scotland, www.socantscot.org with Historic Scotland, www.historic-scotland.gov.uk and the Council for British Archaeology, www.britarch.ac.uk

Editor Colin Wallace

Produced by Archetype Information Technology Ltd, www.archetype-it.com

ISBN: 0903903776

ISSN: $1473-3803$ 


\section{Contents}

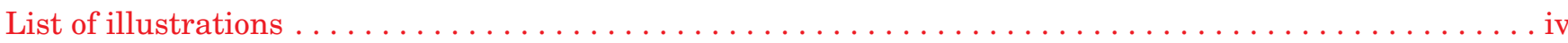

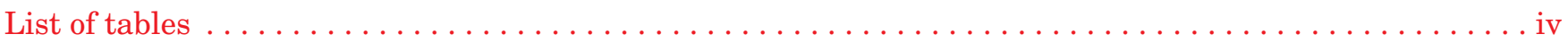

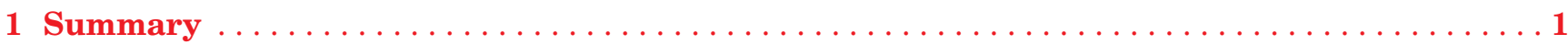

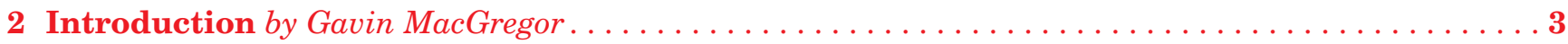

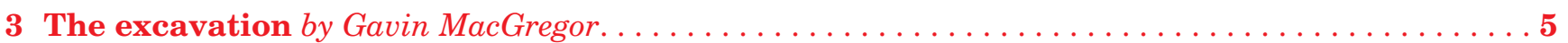

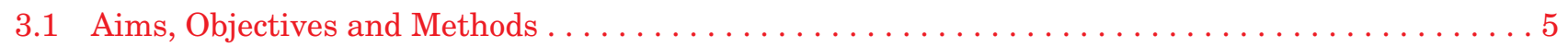

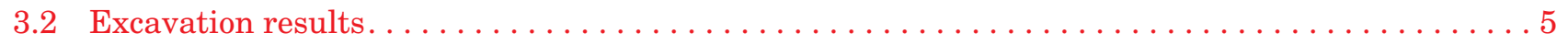

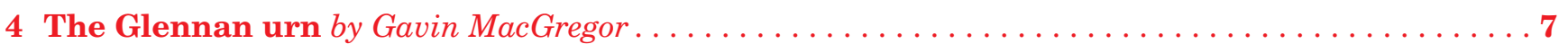

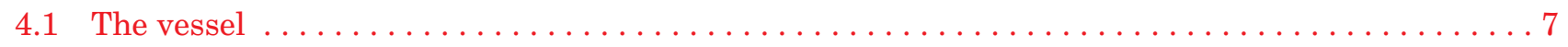

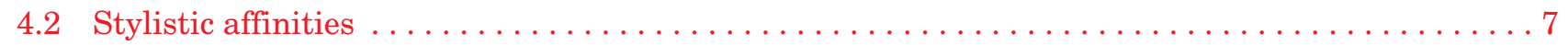

5 The human and animal bones from the urn by Julie Roberts. . . . . . . . . . . . . . . . . . . 9

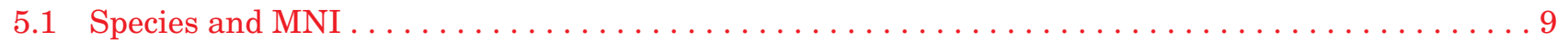

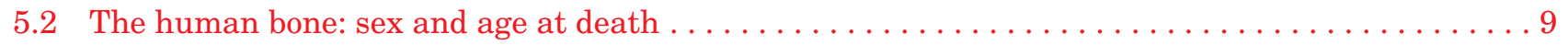

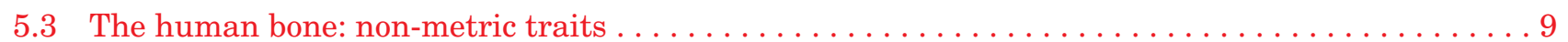

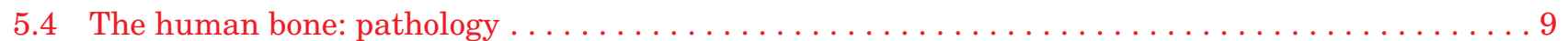

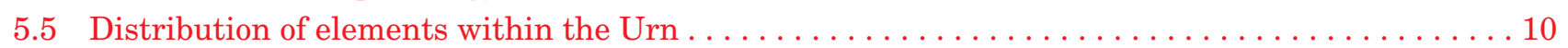

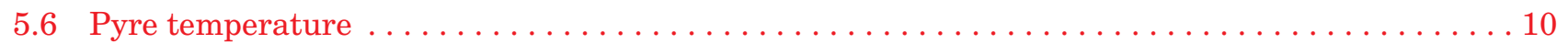

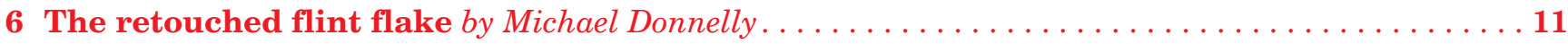

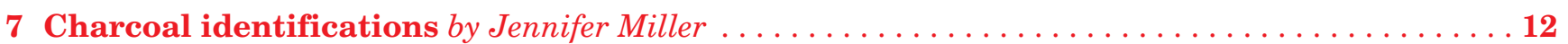

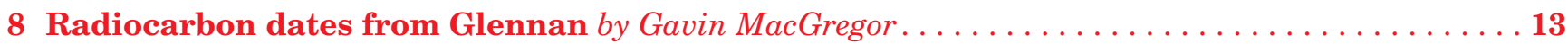

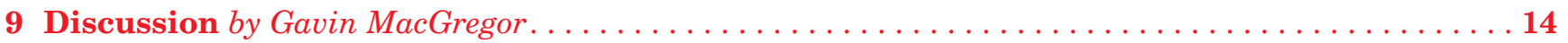

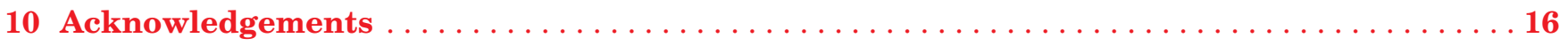

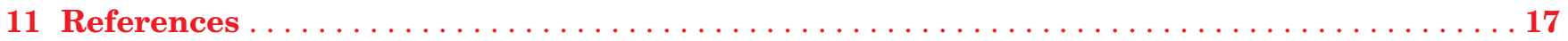

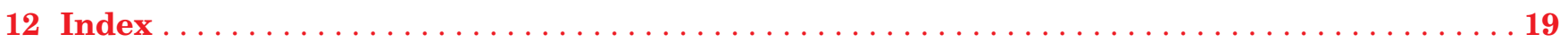




\section{List of illustrations}

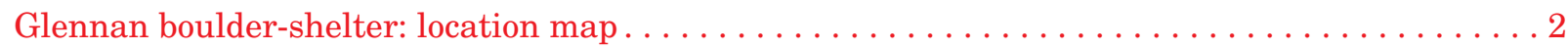

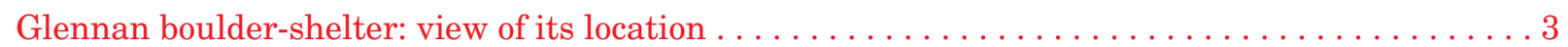

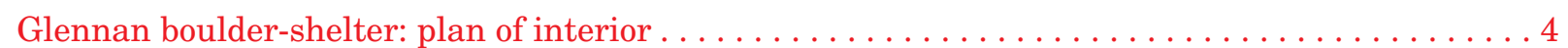

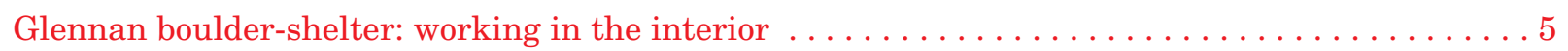

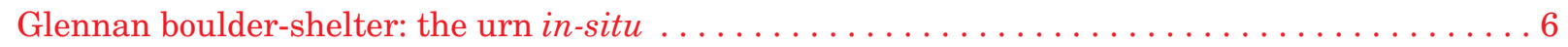

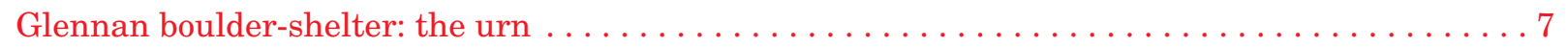

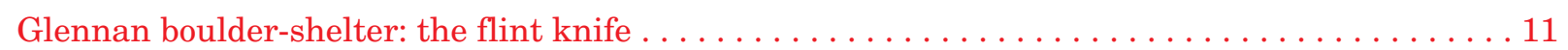

\section{List of tables}

$1 \quad$ Charcoal identification from Glennan. . . . . . . . . . . . . . . . . . . . . . . . . . . . . . . 12

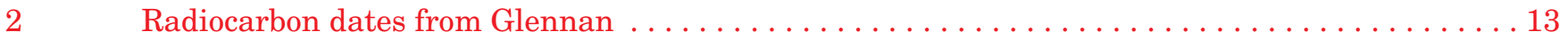




\section{Summary}

As part of the Historic Scotland Human Remains Call Off Contract, Glasgow University Archaeological Research Division (GUARD) undertook an archaeological excavation of a prehistoric urned cremation deposit within a boulder shelter at Glennan, Kilmartin, Argyll and Bute (NGR NM 8622 0097). Analysis has shown the cremation was of a male probably aged between 25 and 40 years. He had suffered from slight spinal joint disease, and mild iron deficiency anaemia, though neither seems likely to have affected his general health. He was cremated shortly after death, together with a young sheep/ goat, and their remains were subsequently picked from the pyre and co-mingled before burial in the urn. An unburnt retouched flint flake was recovered which may have accompanied the burial. The closest parallels for the cremation container are found within the tradition of Enlarged Food Vessel urns, a tradition that is poorly dated but probably has a currency in the first half of the second millennium BC. Radiocarbon dating was problematic: a sample of heather-type charcoal from the fill of the urn was dated and provided a range of cal AD 1260-1390 at 2 sigma (OxA-10281). A second date was obtained from a sample of hazel charcoal from the lowest part of the fill of the urn, which provided a range of 3370-2920 cal BC at 2 sigma (GU-9598).
There are sufficient examples of animal bone previously found accompanying Bronze Age burials to suggest that animals may have had a role in mortuary rites before burial of human remains, though the role and status of these animal remains is not always clear. Although the sample is small, the evidence suggests that, depending on the burial rite, some species of animals were considered more appropriate than others for inclusion; pigs associated with inhumation and goat/sheep associated with cremation burials. The choice of a domesticated animal to accompany the mortuary rites may have been of significance during a period when agro-pastural farming was being widely practiced, and may reflect the perceived inter-relationship between the cultural landscape of people and their livestock.

The context of deposition of an Enlarged Food Vessel urn at Glennan, in a boulder shelter in the uplands, provides an interesting contrast with the known deposition of Food Vessels focused on the valley floor at Kilmartin. It indicates that while many of the more visible ceremonial and funerary sites of the second millennium BC may focus on the floor of the glen, other parts of the landscape were also significant in terms of such activities. 

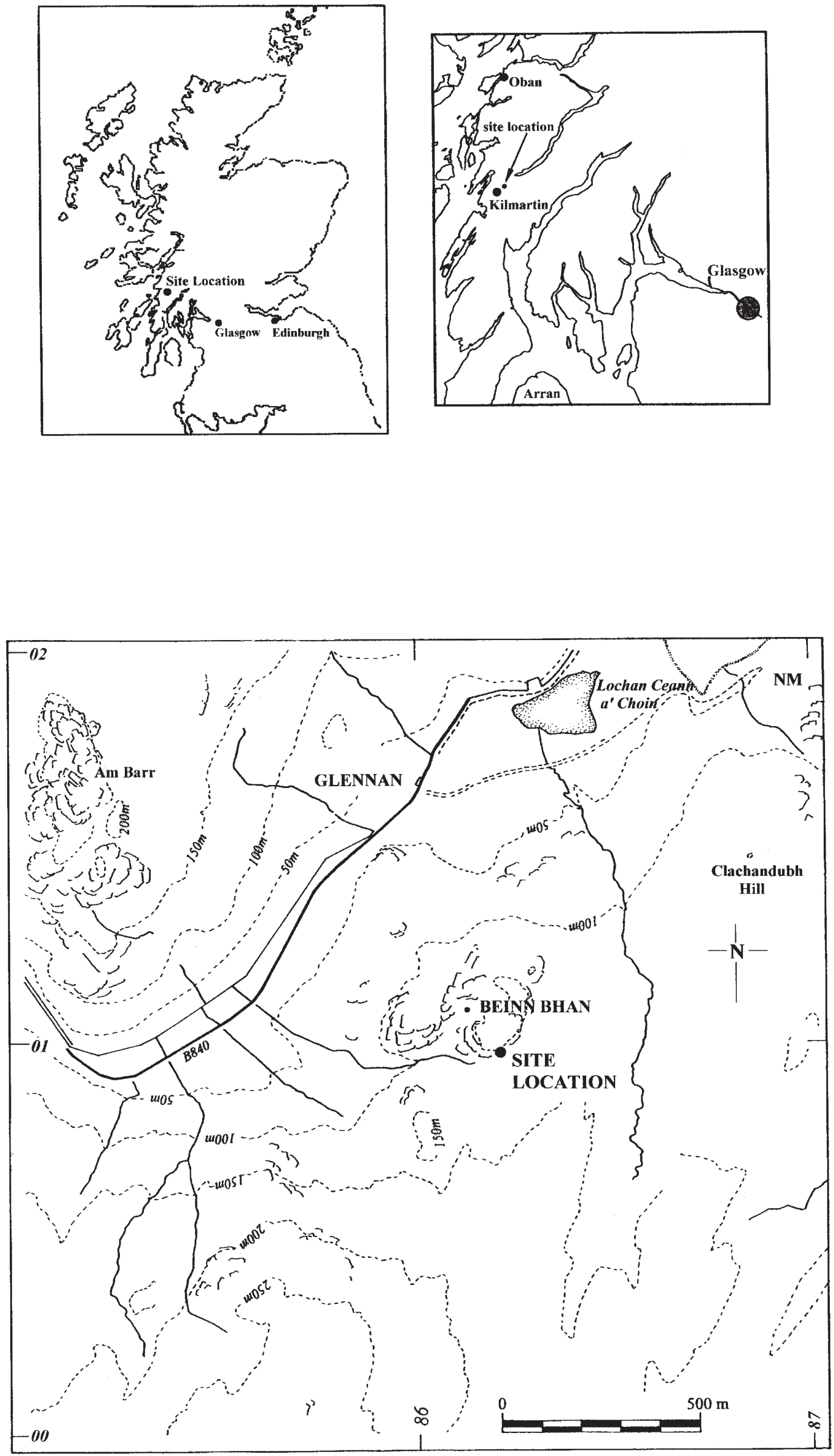

Illus 1 Glennan boulder-shelter: location map 


\section{Introduction by Gavin MacGregor}

The burial was discovered during exploration of a boulder shelter at Glennan. A local bird-watcher had begun to clear the area of the boulder shelter for use as a hide, when burnt bone was recognised amongst spoil from the interior. The discovery was reported to Kilmartin House Museum who contacted West of Scotland Archaeology Service (WOSAS) about the find. WOSAS inspected the site and identified the remains of an urn within the boulder shelter and in turn informed Historic Scotland. This initial exploration had probably resulted in truncation of the urn but to what degree was unclear. An archaeological excavation was eventually undertaken at the site of the find spot, over two days during July and August 2000, as part of the Historic Scotland Human Remains Call Off Contract.
The site is located at Glennan, near Ford, Argyll and Bute (NGR NM 8622 0097: Illus 1). Glennan lies within a small glen running south west to north east between the north end of Kilmartin Glen and Loch Awe. The site of the boulder shelter is at the foot (140 $\mathrm{m}$ OD) of a $20 \mathrm{~m}$ outcrop (Illus 2), located at the northern end of a natural amphitheatre below the peak of Beinn Bhàn.

The specialist reports below are edited versions of the full texts, which form part of the site archive. The site archive has been sent to the National Monuments Record of Scotland, RCAHMS, Edinburgh. The finds have been allocated to Kilmartin House Museum of Ancient Culture by Historic Scotland's Finds Disposal Panel.

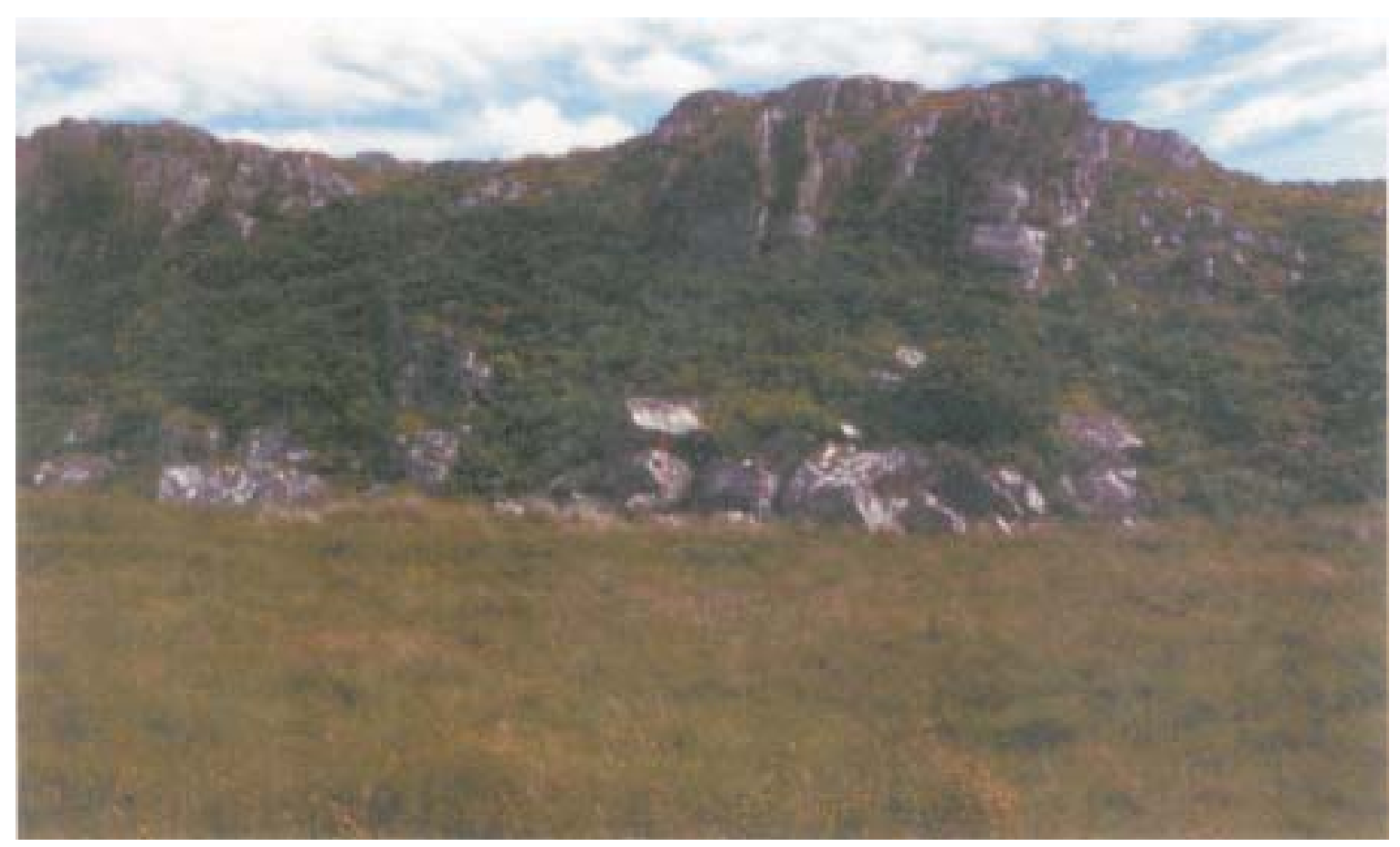

Illus 2 Glennan boulder-shelter: view of its location 

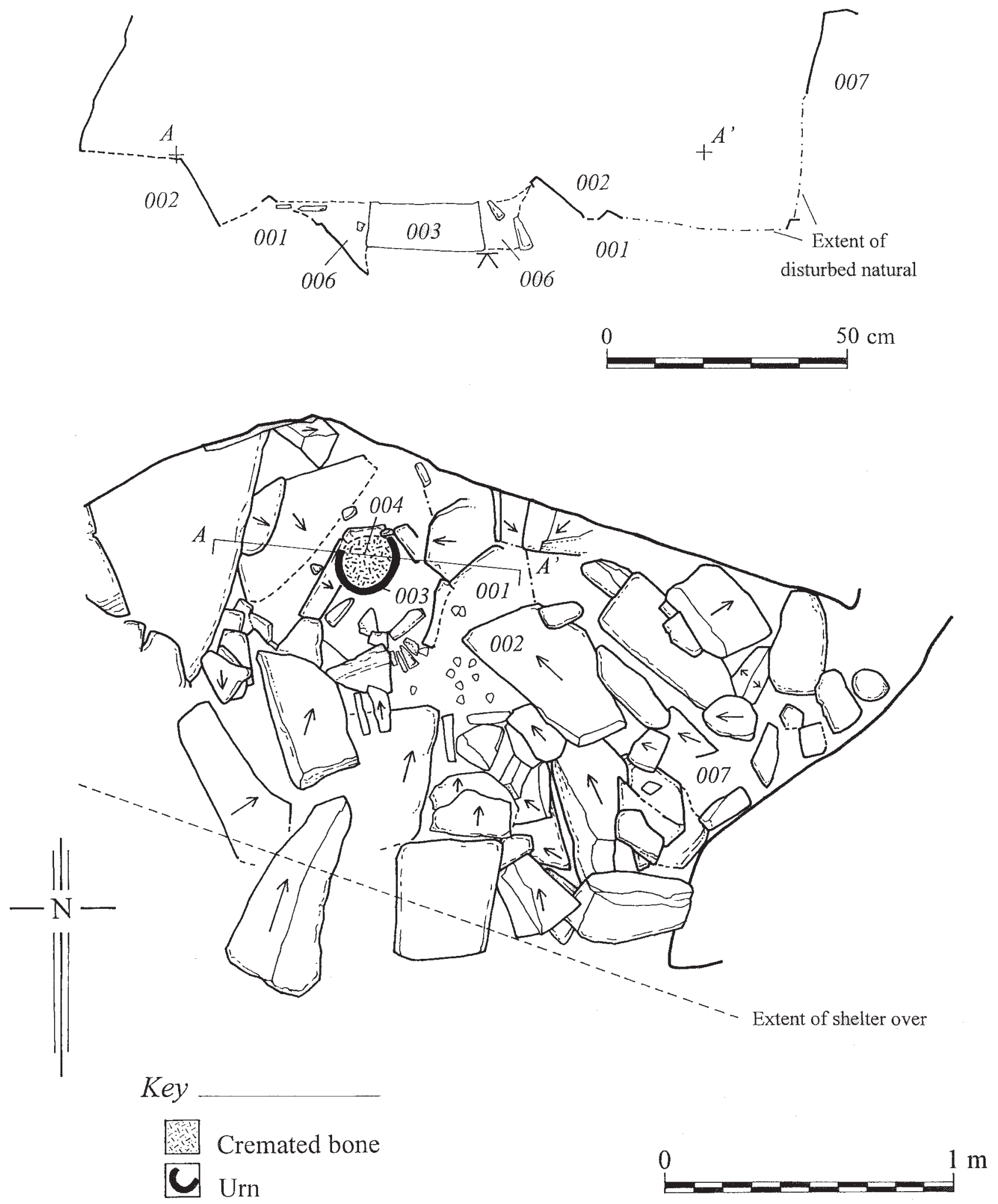

Illus 3 Glennan boulder-shelter: plan of interior 


\section{The Excavation by Gavin MacGregor}

\subsection{Aims, Objectives and Methods}

The excavation aimed to establish whether or not further human remains were present at the site, to establish how the human remains were deposited at the site, the position and location of the urn and whether there were any intimately-related features in the vicinity of the urn. It also aimed to recover all human material associated with the disturbed urn and fragments of the urn from the floor of the shelter and from the scree slope. The interior of the boulder shelter was cleaned and planned. The deposits around the urn were then half-sectioned in order to characterise their nature and extent. The urn (Illus 5) was fully exposed in order to lift it. However, the eroded and friable nature of the urn prevented lifting of the contents intact for laboratory excavation. Consequently, its contents were excavated in-situ utilising $20 \mathrm{~mm}$ spits and quadrants to record bone location. All deposits within the urn were bagged with the cremated bone according to this sampling strategy. All further material from the site, including the original spoil, was dry sieved in order to maximise recovery of human remains and artefacts.

\subsection{Excavation Results}

The site comprised two massive boulders resting on smaller rocks and boulders within or on a scree slope (Illus 3). The interior of the boulder shelter currently has a maximum height of $0.5 \mathrm{~m}$ and measures $c 2.5 \mathrm{~m}$ by $2.5 \mathrm{~m}$. The interior was filled with rocks and cave earth (context 007). The area of disturbance relating to the original discovery by the bird-watcher was at the western end of the shelter and was sub-circular, $c$ $1 \mathrm{~m}$ in diameter, extending a further $0.3 \mathrm{~m}$ below the floor level. Rocks could be seen to pitch downwards into the interior of the boulder shelter but had no structural coherence or integrity. The mouth of the boulder shelter had been at least partially blocked by crude stone walling (Illus 4, bottom right of picture).

Cleaning of the surface around the urn produced a quantity of burnt bone and a few sherds of pottery. Excavation of the urn revealed that it had been placed into an irregular pit (005), measuring $c 0.5 \mathrm{~m}$ in diameter, cut through the deposits of the boulder shelter floor (001/002) (Illus 3). The scree within the floor deposit pitched downwards from west to east. It was clear that pit 005 had been formed by pulling out slabs from the scree deposit. The urn had been placed

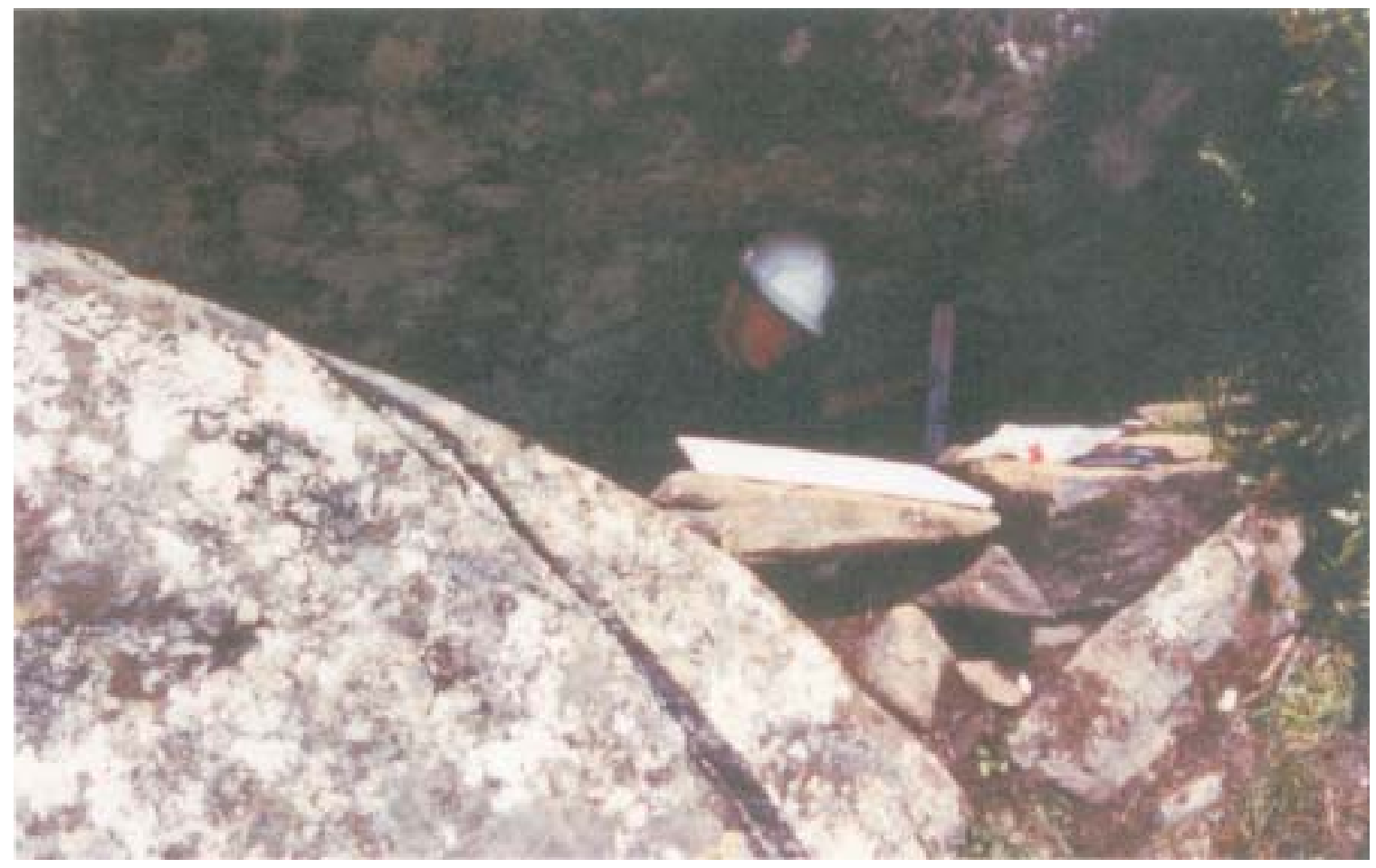

Illus 4 Glennan boulder-shelter: working in the interior 


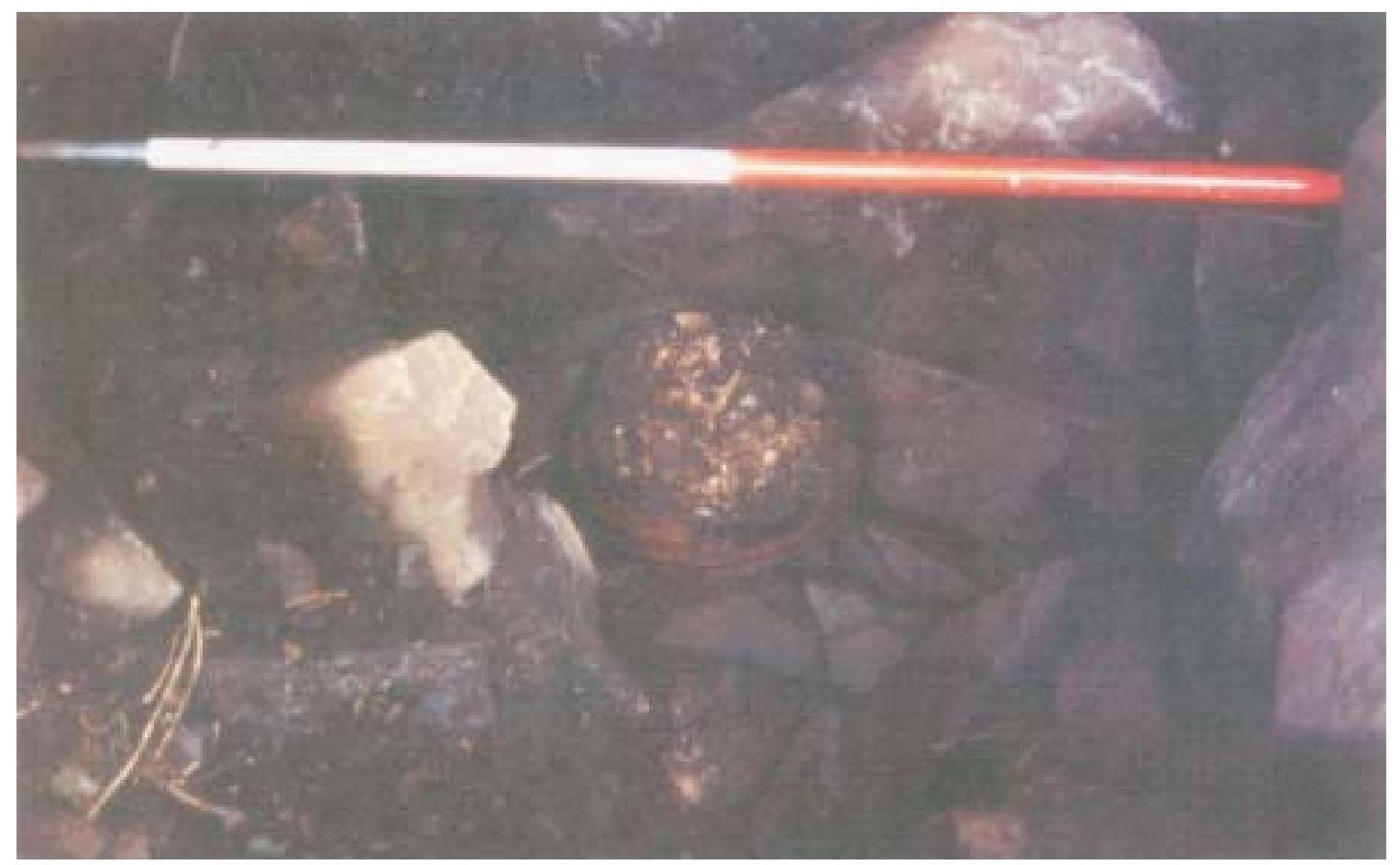

Illus 5 Glennan boulder-shelter: the urn in-situ

inverted, containing the cremation deposit (004) within the pit, which was then backfilled (006). Only the upper $0.15 \mathrm{~m}$ of the urn, which relates to the Enlarged Food Vessel tradition (see Section 4.2 below), survived in-situ (Illus 5). Sieving of the exterior spoil produced a quantity of burnt bone, a few sherds of pottery and a retouched flint flake (Illus 7; see Section 6). 


\section{The Glennan Urn by Gavin MacGregor}

Fifteen major sherds of prehistoric pottery were recovered from excavations at Glennan. Each sherd or group of sherds recovered was examined to produce a basic catalogue and to distinguish between sherds from potentially different vessels. Fabric analysis was undertaken only at a macroscopic level. Any observations must, therefore, be considered provisional unless or until confirmed by microscopic analysis. Conservation of the urn was undertaken at AOC Archaeology in Edinburgh and involved consolidation and joining of the major sherds (AOC 2000).

The total weight of pottery, including sherds, fragments and crumbs, is $1374.4 \mathrm{~g}$. About $30 \%$ of a single pottery vessel is represented by the upper part of the body, which was preserved in-situ prior to excavation by GUARD. Up to $90 \mathrm{~mm}$ in depth of the profile is present and $95 \%$ of the rim. The remaining lower portion of the vessel was not preserved and had been destroyed at some point in the past.

\subsection{The Vessel (Illus 6)}

The vessel had an external diameter of $260 \mathrm{~mm}$ at the mouth. The rim is rounded, expanded on the exterior, with an internal bevel and is $c 21 \mathrm{~mm}$ wide at the point the bevel returns to the wall. There are two cordons on the upper body of the vessel, each $c 15$ $\mathrm{mm}$ wide and $15 \mathrm{~mm}$ apart. The cordons have been pinched out from the top of the building ring. The wall thickness varies between $13 \mathrm{~mm}$ and $15 \mathrm{~mm}$.

The exterior of the vessel is decorated with horizontal rows of impressed decoration, with up to seven of these present. The upper five rows of decoration consist of cord twisted 'maggot'. Each 'maggot' slopes diagonally, is $c 10 \mathrm{~mm}$ in length and $c 3 \mathrm{~mm}$ wide. Together they form a herringbone motif. The 'maggot' decoration on the second and fourth row differs in as much as a blunt ended tool has been used to press the cord in deeper, creating a 'cross-maggot' motif. The decoration below the second cordon is stabbed with what may be a hollow bone tool. Two rows are represented on the surviving portion of the body.

The vessel has a coarse friable clay fabric with frequent inclusions protruding through the interior surface. The exterior has been carefully finished, as only occasional inclusions protrude. The inner surface is a light grey to buff while the exterior is predominantly buff with small patches of orange. The vessel is handmade (ring construction is visible in several sherds) and has probably been fired in an open bonfire.

Basic macroscopic analysis of the sherds indicates that the vessel has inclusions of grey angular to sub-angular igneous rock. The inclusions are moderately well sorted, have a frequency of $c 25 \%$ and are up to $13 \mathrm{~mm}$ in length.

The surviving portion of the vessel shows no clear evidence of use, there being no visible residues or encrustations present on its surfaces. The surfaces themselves show little or no sign of abrasion relating to potential use.

\subsection{Stylistic Affinities}

The Glennan urn falls within the tradition of Enlarged Food Vessel urns (cf Cowie 1978, 20-24).
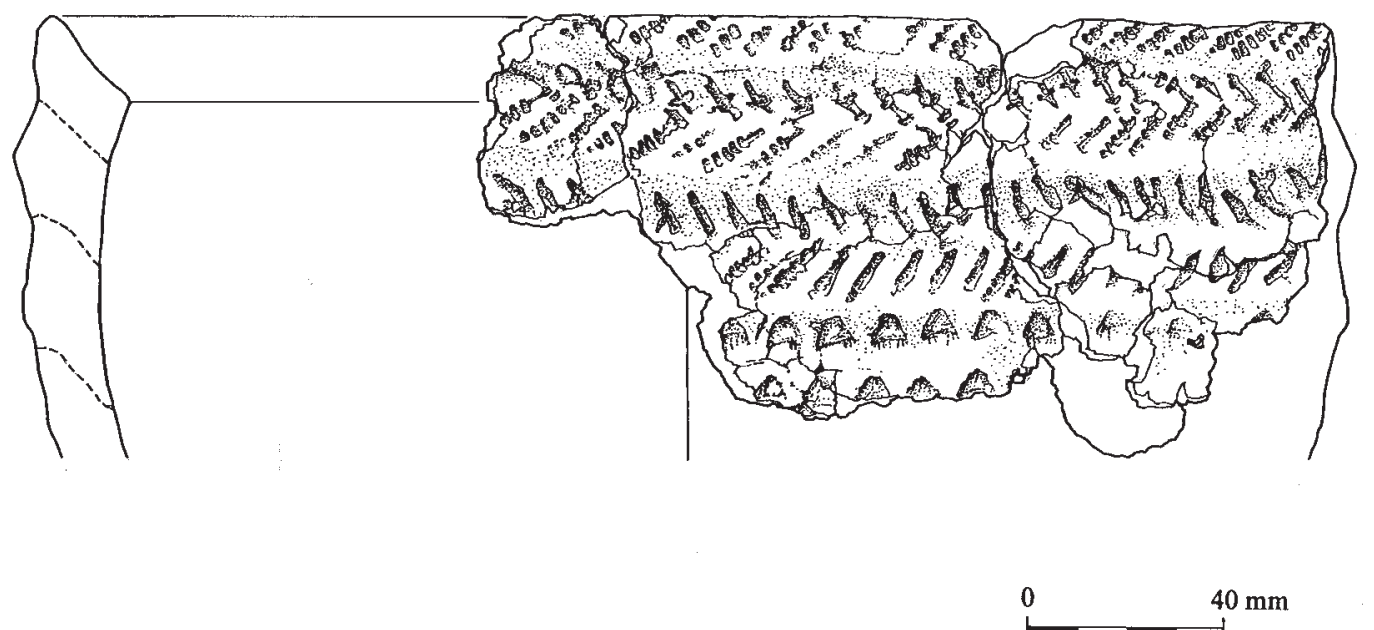

Illus 6 Glennan boulder-shelter: the urn 
Until recently, the Enlarged Food Vessel urn tradition was poorly dated but a currency in the first half of the second millennium BC was suggested (ibid.). Now, results from the National Museums of Scotland Dating Cremated Bones Project demonstrate that such vessels were definitely in use around (or just before) 2000BC (Sheridan 2003, 203-06). Some writers (Sheridan 2003, 217 [note 1]) prefer the term 'Vase Urns' for these vessels.
The distribution of Enlarged Food Vessels from Scotland focuses towards the east, with few examples from the west coast (cf. Sheridan 2003, fig 13.3). The geographically closest examples of Enlarged Food Vessel urns are from Glenvoidean, Bute (Marshall and Taylor 1977, 24-25) and Glen Cloy, Arran (Soc Antiq Scot 1865, 83). The Glennan urn thus adds to the small corpus of known vessels from the west coast of Scotland and extends their distribution further north. 


\section{The human and animal bones from the urn by Julie Roberts}

Excavation of the bone from the urn was undertaken in the field (Section 3.2). The remains were removed in four spits, each of which was divided into quadrants. This strategy was designed to facilitate an assessment of the distribution of specific skeletal elements throughout the deposit as a whole.

Each spit and quadrant of bone was passed through a stack of sieves with $10 \mathrm{~mm}, 5 \mathrm{~mm}$ and 2 $\mathrm{mm}$ meshes. The amount of bone within each fraction was weighed, analysed, and recorded in a skeletal inventory. Due to the constraints of time, it was not possible to extract the bone measuring $<2$ $\mathrm{mm}$ in diameter from the soil matrix. The material was examined, however, in its entirety and any diagnostic fragments of bone or dentition were removed and recorded.

The proportion of identified and unidentified elements within each fraction was recorded. Fragments were termed unidentified if they could not be ascribed to a specific element or body area, ie cranial, axial, upper limb and lower limb. Overall, the preservation of the remains from Glennan was very good. The total weight of the bone from the urn was $1511.7 \mathrm{~g}$ (excluding the $<2 \mathrm{~mm}$ fraction).

\subsection{Species and Minimum Number of Individuals}

Species was determined macroscopically, on the basis of the morphology, surface texture and density of the fragments. Of the $1511.7 \mathrm{~g}$ of bone analysed, $1478.5 \mathrm{~g}$ was found to be human and $33.2 \mathrm{~g}$ was found to be animal. In the case of the human bone, a minimum number of just one individual was identified, based on the absence of any repeated skeletal elements or elements belonging to individuals of clearly different biological age. As noted above, a quantity of non-human bone was identified. All the fragments appeared to be from the same animal, an immature sheep/goat. Multiple fine transverse lines were evident on the shaft of the tibia, that may have been associated with skinning the animal.

\subsection{The human bone: sex and age at death}

Amongst the remains, several sexually dimorphic cranial and pelvic elements were sufficiently well preserved to be used in the determination of sex. These included the orbital rims and superior temporal line of the frontal bones, the zygomatic bones, and the sciatic notch and auricular surface of the ilium. All of the above indicated a male sex. In addition the morphology of the first sacral vertebra was male, and the long bones were robust, with cortical measurements falling within the male range (Gejvall 1963).

With regard to age at death, several diagnostic elements had survived. The roots of the third molar were intact and fully developed, indicating an age of greater than 18-21 years. The first and second sacral vertebrae had fused indicating an age of greater than 22-25 years, and the epiphysis of the medial end of the clavicle had also fused, indicating an age of greater than 25-29 years at death. The medial end of the clavicle is the last epiphysis to fuse in the body and, once this occurs and skeletal maturity is attained, methods of age determination become less precise. It was possible to use the appearance of the pubic symphysis and the auricular surface of the ilium as a guide, although the elements were not quite complete. An age of between 30 and 40 years at death was suggested, which was consistent with the lack of degenerative changes observed on almost all of the other surviving joint surfaces. In addition, the heat of the fire had caused the cranium to fracture along the suture lines on several occasions, indicating that they were not fully fused, which indicates that the individual was probably younger than middle-aged.

\subsection{The human bone: non-metric traits}

Three non-metric traits were identified: two cranial ossicles (one in the right coronal suture), a right extra-sutural mastoid foramen, and Allens fossa, on the left femur. All of these traits are commonly observed in archaeological populations, and cannot be attributed to any specific activity or environmental factor.

\subsection{The human bone: pathology}

The individual had suffered from mild spinal joint disease and iron deficiency anaemia. The spinal joint disease was characterised almost entirely by schmorls nodes, which were present on the surfaces of four thoracic vertebrae and one lumbar vertebrae. Often they are the result of a compression force which might be sustained during heavy lifting or in a fall onto the feet, and they may accompany actual compression fractures (Roberts and Manchester 1995, 107-08). In addition, five fragments of lumbar vertebra and one fragment of thoracic vertebra displayed evidence of slight porosity, and one lumbar vertebra, had a slight osteophytic projection. These 
minor changes indicate mild degenerative disease in its early stages. It is unlikely that this level of severity would have caused a great deal of pain, or limited mobility. Iron deficiency anaemia was evident, characterised by porotic hyperostosis, a pitting and thickening of the outer layer of the skull. Two fragments of parietal and two fragments of unidentified cranium displayed these lesions. In the case of the male from Glennan, the manifestation was not severe and it is unlikely that he would have been debilitated by the condition.

In view of the good state of preservation of the remains, in particular the survival of many of the joint surfaces, there was surprisingly little pathology present. The only evidence of osteoarthritis on elements other than the vertebrae, was on a single carpal bone and a rib. These were very minor changes that would almost certainly have been asymptomatic.

\subsection{Distribution of Elements within the Urn}

No clear pattern could be identified with regard to the horizontal and vertical distribution of the different skeletal elements. No concentrations of specific elements or elements from the same region of the body were found in any particular spit or quadrant. This indicates that the human remains were well mixed following removal from the funerary pyre and before deposition within the urn.

The non-human bone was also mixed throughout the deposit, being found in every spit and every quadrant. This strongly suggests that the animal was cremated on the same pyre as the adult male, and that their remains were mixed together before burial. The lack of fuel ash slag and any other extraneous material in the urn suggests that both the human and animal remains were picked carefully from the pyre (and possibly even washed) before they were mixed together and deposited in the urn for burial. Careful sorting and cleaning from pyre material is more likely in light of the problematic radiocarbon dates obtained from the charcoal found in association with the burial.

\subsection{Pyre Temperature}

Distinct and consistent colour changes have been observed in heat-treated human bone and are white when all the organic matter is combusted and cremation is complete at temperatures in excess of $700-800^{\circ} \mathrm{C}$ (Holden et al 1995; Shipman et al 1984). The fragments from Glennan were predominantly white indicating that the technology employed by the community concerned was sufficiently advanced to create and sustain enough heat to completely cremate their dead.

There was no evidence of differential combustion that might suggest a particular body position on the pyre, as observed in other Bronze Age cremation burials (Holck 1986; Roberts 1998; Roberts 2000). This suggests that the pyre was well tended and stoked in order to allow a free flow of oxygen to all body parts. Evidence of fragmentation incurred during the cremation process, perhaps by stoking the pyre, was seen in a few fragments of frontal and parietal bones that were slightly different in colour. It is possible that the cranium was fractured, and those fragments that were grey in colour had been pushed to the peripheries of the pyre, or had lain at the bottom in a layer of ash. The cracking patterns that were evident on many of the bones and the warpage of several of the larger fragments were an indication that the body had been cremated soon after death, whilst still fleshed (Ubelaker 1989, 36-38). 


\section{The retouched flint flake by Michael Donnelly}
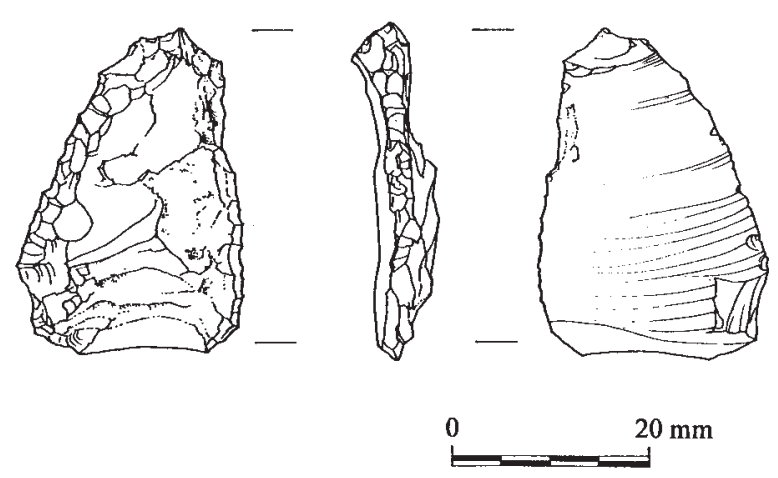

Illus 7 Glennan boulder-shelter: the flint knife

Flint, $26 \mathrm{~mm} \times 23 \mathrm{~mm} \times 6 \mathrm{~mm}$, plunging secondary flake, heavy platform preparation, flat bulb, flat platform with distinct lip. Regular, medium, parallel, semi-abrupt retouch along dorsal, right margin; regular, fine retouch along dorsal, left margin, low to moderate stepping to both edges and an area of severe edge damage to lower right margin; slight snap at extreme lower right margin (small find 2 , from sieving of spoil).

The flint flake (Illus 7) is typical of many finds discovered in association with Bronze Age urns from Scotland. Finds such as discoidal scrapers, barbed and tanged arrowheads (Temple Wood, Kilmartin: Scott 1991, 101-03) and true knives (Upper Largie, Argyll: Mercer and Rideout 1987, 37-38) are prominent within this material and parallels for the Glennan example are less evident although they do exist with numerous examples from Tayside and Fife (eg Kirkton: MacGregor 1998a, 74). Often, many flint flakes with simple retouch or with abrupt retouch are described as knives and it is possible to view this piece as easily fitting into this looser grouping.

The piece had clearly been used during its lifetime, although some of the more severe edge damage might relate to its deposition within the spoil from the initial discovery of the urn. The piece does not display signs of having been affected by high temperatures. 


\section{Charcoal identifications by Jennifer Miller}

Seven small samples of charcoal from contexts 001 (shelter floor) and 004 (cremation deposit) were presented for identification of taxa and assessment of dating potential (Table 1). Four of the samples contained material of sufficient weight to permit AMS dating (Section 8). Taxa identified included Betula (birch), Corylus (hazel), Ericaceae undifferentiated (heather type), Prunus spinosa type (sloe type) and Quercus (oak). Charcoal was generally in good condition, although fragments were small and few in number. The remains are deemed to be of Bronze Age origin by association to the funerary urn and indeed the assemblage found is typical of the mixed deciduous open woodland identified as native to the Kilmartin Valley area at that time from both pollen and macrofossil evidence (Miller, Ramsay and Housley forthcoming). The small number of fragments means that it is not possible to ascertain whether there was any particular selection of taxon for burning rather than just the utilisation of available resources.

Table 1 Charcoal identifications

\begin{tabular}{|c|c|c|c|c|c|c|}
\hline Sample & Betula & Corylus & Ericaceae & $\begin{array}{c}\text { Prunus Spinosa } \\
\text { type }\end{array}$ & Quercus & Indet \\
\hline 004 BS1 & & $0.1 \mathrm{~g}(3)^{*}$ & & & & $0.05 \mathrm{~g}(2)$ \\
\hline 004 bone surface & $0.05 \mathrm{~g}(1)$ & & & & & \\
\hline 004 spit 1 & & & $0.1 \mathrm{~g}(1)^{*}$ & & $0.1 \mathrm{~g}(1)$ & \\
\hline 001 bone surface & $0.1 \mathrm{~g}(1)$ & & & & & \\
\hline 004 spit $1 \mathrm{C}$ & $<0.05 \mathrm{~g}(4)$ & & & & & \\
\hline 004 spit 3B & $<0.05 \mathrm{~g}(3)$ & & & $<0.05 \mathrm{~g}(1)$ & & $<0.05 \mathrm{~g}(1)$ \\
\hline 004 spit 4D & $<0.05 \mathrm{~g}(1)$ & $<0.05 \mathrm{~g}(1)$ & $<0.05 \mathrm{~g}(2)$ & & & \\
\hline
\end{tabular}

Note: the figure in brackets beside the weight shows the number of fragments identified). Samples marked* were used for AMS dating. 


\section{Radiocarbon Dates from Glennan by Gavin MacGregor}

An initial sample of single entity Ericaceae charcoal from the fill of the urn (Table 1, context 004 spit 1) was sent for accelerator dating at the Oxford Radiocarbon Accelerator Unit. A date was obtained of cal AD 1260-1390 at 2 sigma (OxA-10), which was clearly too late for a prehistoric burial. Consequently, a second sample of single entity Corylus charcoal from the lowest part of the urn fill (Table 1, context 004 BS 1) was submitted for accelerator dating at the Scottish Universities Research and Reactor Centre. The date obtained was 3370-2920 cal BC at 2 sigma (GU-9598). The dates were calibrated on OxCal v3.5.

While care was taken to select single entity charcoal samples from the fill of the urn, both of the radiocarbon dates obtained are problematic. The first date obtained of cal AD 1260-1390 (OxA-10281) is clearly too recent. The sample dated probably represents intrusive material. The second radiocarbon date of 3370-2920 cal BC (GU-9598) would universally be considered too early for the burial tradition (Section 4.2).

While both samples may simply represent carbonised material deriving from natural fires that migrated into the boulder shelter, they may also indicate human agency in the vicinity during the Neolithic and Medieval periods. A combination of both processes may have been at work; the carbonised remains had to derive from somewhere and the water could easily have washed charcoal from natural fires in the shelter. The earliest radiocarbon date may indicate that the shelter had been used by people before insertion of a formal burial. While the later one suggests that the boulder shelter could have been reused during the Medieval period and that the activities which took place then may have been the cause of the truncation of the base of the urn.

$[E d .:$ In view of the contribution of dated urns of this type to the research question about the emergence of inurned cremation in Bronze Age Scotland, it is intended to resolve the problematic radiocarbon dating of the Glennan Enlarged Food Vessel urn (or Vase Urn) at a later time, perhaps using the new bio-apatatite dating technique pioneered at Groningen to produce a third date. Given the long process necessary for securing funding and permission for this work, it was not felt reasonable to use this matter to delay publication any further.]

Table 2 Radiocarbon dates from Glennan

\begin{tabular}{llcccc}
\hline Lab Code & Sample Material & Lab. Age BP & $\delta$ C13 & Calibrated 1 sigma & Dates 2 sigma \\
\hline OxA-10281 & Ericaceae charcoal & $700 \pm 33$ & -24.9 & AD 1270-1390 & AD 1260-1390 \\
GU-9598 & Corylus charcoal & $4495 \pm 75$ & -28.1 & $3350-3090$ BC & $3370-2920$ BC \\
\hline
\end{tabular}




\section{Discussion by Gavin MacGregor}

Analysis of the Glennan urn and its contents has shown that a single adult male was cremated with at least part of a goat/sheep. There are sufficient examples of animal bone previously found accompanying Bronze Age burials to suggest that animals may have formed a role in mortuary rites before burial of human remains. The role and status of these animal remains is not always clear; they may have been the remains of feasting, sacrifice on pyres or employed in ceremonies with symbolic connotations.

In the case of the Glennan burial, analysis has shown that marks on the bones may relate to skinning of the animal (see Section 5.1). Indeed it is not inconceivable that the flint knife that probably accompanied the burial and which shows signs of use (Section 6) was indeed used for this particular purpose. Skinning would be in keeping with butchery of the animal and when considered in conjunction with the small proportion of the animal represented within the cremation deposit it suggests that only a proportion of a butchered animal had been placed as an offering on the pyre. The rest could have been eaten by the mourners, for in the cases of several Bronze Age inhumation burials discussed below, the deceased was buried with just a portion.

There are other examples of cremated animal bone from Bronze Age burials. Burnt animal bone identified as sheep/goat was present within three cremation burials (068, 082 and 056) at Cloburn Quarry, Lanarkshire (Lelong and Pollard 1998, 122). A radiocarbon date was obtained, from charcoal within burial 082, of 1910-1620 cal BC (Beta-111007). At Horsburgh Castle Farm, Peebleshire a cremation burial, which had been inserted above a short cist, contained fragments of scapula, tibia, humerus and mandible of sheep (Denston 1974, 57).

There are also several examples of pig 'joints' accompanying Bronze Age burials. At Gairneybank, Perth and Kinross, a cist (cist 3) containing an inhumation was accompanied by the right humerus, radius and ulna of a pig (Cowie and Ritchie 1991, 98). A radiocarbon date of $2300-1600 \mathrm{cal} B C$ (GU-1120) was obtained from the burial (revised date from the Historic Scotland date-list on their website, www.historic-scotland.gov.uk). At Muirhill, Perth and Kinross, pig bones, sea urchin spines and a flint knife (Stewart and Barclay 1997, 43), accompanied a crouched inhumation in a short cist. A radiocarbon date of $1900-1623$ cal BC (AA-22180) was obtained from the burial. Similarly, at Aberdour Road, Fife, a cist (cist I) contained a crouched inhumation that was accompanied by the fore-limb bones of three pigs (Close-Brooks et al 1972, 123 and 132). At Grainfoot,
East Lothian, pig fore-limb bones were recovered with two inhumations in a short cist (Dalland 1991, 113). A radiocarbon date of 1310 - 940 cal BC (GU-2762, revised as the Gairneybank date, above) was obtained from human bone. The unburnt humerus and radius of a pig was found with inhumations and beaker at Uppermill, Aberdeenshire (Harman 1977, 90).

Although the sample is small, this evidence suggests that different species of animals were considered more appropriate for inclusion in different burial rites during this period; pigs associated with inhumation and goat / sheep associated with cremation. The choice of a domesticated animal to accompany the mortuary rites may have been of significance during a period when agro-pastural farming was being widely practiced, and may reflect the perceived inter-relationship between the cultural landscape of people and their livestock. While we see potential distinctions drawn out in terms of what animals were appropriate to accompany different burial rites, in both cremation and inhumation the animal parts deposited were partial. This may suggest that the mourners were consuming the remainder of the animal and indeed that the deposition of part of the animal with the deceased related to a concept of sharing between the living and the dead.

Analysis by Julie Roberts suggests that the skeletal remains from the pyre were carefully collected and probably cleaned before insertion in an Enlarged Food Vessel urn (Section 5.5). The surviving portion of the vessel shows no obvious signs of previous use and may have been constructed solely for the purpose of burial (see however MacGregor 1998b, 156-57). An unburnt retouched flint flake may have accompanied the burial (Section 6). It is unclear whether it had been placed at the base of the urn before inserting the cremation or adjacent to it within the upper fill of the pit cut.

Whether the cremation took place close to the boulder shelter or lower down in the bottom of a nearby glen is, however, unknown. As there was no slab beneath the urn, it was probably originally covered with skin or cloth before its inversion and could, therefore, readily have been carried from some distance away.

While the insertion of the Glennan cremation vessel into a pit in an inverted position is typical of cinerary urns of this type at this time, its context of deposition within a boulder shelter is more unusual. However Enlarged Food Vessels have been found within a rock shelter cemetery at Goatscrag, Northumberland (Burgess 1972, 52-55). Other types 
of cinerary urn burial are known from caves/rock shelters throughout Britain.

More locally, there are several other examples of the use of cave sites, in the broadest of senses, for funerary purposes during the second millennium BC from the west of Scotland (Tolan-Smith 2001, 5-9). These include a rock cleft at Carding Mill Bay, Oban, where fragments of a Food Vessel were found in association with human bone (Connock et al 1993, 29) and the rock shelters at Crinnan Ferry, Knapdale, where 'urns' including Beaker were discovered in conjunction with human bone (Mapleton 1881; Campbell and Sandeman 1964, 21 [no 148]). Although it is unclear whether or not it was accompanied by human remains, the discovery of a Food Vessel in a boulder shelter at Creag An Eig, Benderloch, is suggestive of ceremonial activity (Smith 1873, 82/88). Also of note was the discovery of Beaker pottery from Tinkler's Cave, Loch Fyne (Tolan-Smith 2001, 159), the presence of which could suggest funerary or ceremonial activity in the cave.

The majority of earlier Bronze Age vessels from Kilmartin Glen have been Food Vessels (RCAHMS 1999, 10-11 and 108-09), with one example having been found in a cist near Ford (Soc Antiq Scot 1886, 73-74). The context of deposition, from a boulder shelter in the uplands, of the Glennan Enlarged Food Vessel urn provides an interesting contrast with the deposition of such vessels focused on the valley floor. It indicates that while many of the more visible ceremonial and funerary sites of the second millennium $\mathrm{BC}$ may focus on the floor of the Glen, other parts of the landscape were also significant in terms of such activities. This pattern can also be contrasted in the location of the rock art in the Kilmartin Glen area, which is more frequently situated up from the valley floor, and later incorporated in ceremonial or burial monuments built on the floor of the Glen during the second millennium BC (Stevenson 1997, 101-09). Whether the location for the burial of the Glennan urn was chosen because it was outwith the landscape of daily activity or whether it is a reflection of the regular use of the uplands is unclear. In particular, as the Enlarged Food Vessel urn reflects a different ceramic tradition from that represented by the bowl Food Vessels of Kilmartin Glen, it raises interesting questions about interaction as much as it adds to our understanding of the use of the glens beyond Kilmartin during the second millennium BC. 


\section{Acknowledgements}

The fieldwork was undertaken with the assistance of Paul Duffy. The project was specified and funded through to publication by Historic Scotland. The project was monitored by Paul Robins of West of Scotland Archaeology Service. The project was managed for GUARD by Beverley Ballin-Smith and the report was copy edited by Olivia Lelong. Gary Tompsett and Caitlin Evans prepared the illustrations. My particular thanks go to Debbie Long and staff at Kilmartin House Museum for their help during the excavation of the urn and to the SAIR referee for their comments on the text. 


\section{References}

AOC 2000 Glennan, Kilmartin: Conservation of a ceramic vessel from a cist burial $[=\mathrm{AOC}$ Project No 3334].

Burgess, C B 1972 'Goatscrag: A Bronze Age Rock Shelter Cemetery in north Northumberland', Archaeologia Aeliana 4ser 50 (1972), 15-69.

Campbell, M and Sandeman, M 1964 'Mid Argyll: an archaeological survey', Proc Soc Antiq Scot, 95 (1961-2), 1-125.

Close-Brooks, J, Norgate, $\mathrm{M}$ and Ritchie, J NG 1972 'A Bronze Age cemetery at Aberdour Road, Dunfermline, Fife', Proc Soc Antiq Scot 105 (1972-74), 121-36.

Connock, K D, Finlayson, B and Mills, C M 1993 'Excavation of a shell midden site at Carding Mill Bay near Oban, Scotland', Glasgow Archaeol J 17 (1991-2), 25-38.

Cowie, T G 1978 Bronze Age food vessel urns in northern Britain. Oxford. [ = Brit Archaeol Rep British series 55].

Cowie T and Ritchie J N G 1991 'Bronze Age burials at Gairneybank, Kinross-shire', Proc Soc Antiq Scot. 121 (1991), 95-110.

Dalland M 1991 'A short cist at Grainfoot, Longniddry, East Lothian', Proc Soc Antiq Scot 121 (1991), 111-16.

Denston, C B 1974 'Cremated remains from Horsburgh Castle Farm' in Peterson, F, Shepherd, I A and Tuckwell, A N 'A short cist at Horsburgh Castle Farm, Peebleshire' Proc Soc Antiq Scot 105 (1972-4), 43-62.

Gejvall, N G 1963 'Cremations', in Brothwell D and Higgs, E (eds.) Science in Archaeology, 379-90, London.

Harman, M 1977 'The Bones from Uppermill' in Kenworthy, J B 'A reconsideration of the 'Ardiffery' finds, Cruden, Aberdeenshire', Proc Soc Antiq Scot 108 (1976-7), 80-93.

Holck, P 1986 Cremated Bones: A Medical-Anthropological Study of Archaeological Material on Cremation Burials. Oslo [ = Anthropologiske Skrifter 1, Anatomical Institute, University of Oslo]

Holden, J L, Phakey, P P and Clement, J G 1995 'Scanning Electron Microscope Observations of Heat- Treated Human Bone', Forensic Science International 74 (1995), 29-45.

Lelong, O and Pollard, T 1998 'Excavation of a Bronze Age ring cairn at Cloburn Quarry, Cairngryffe Hill, Lanarkshire', Proc Soc Antiq Scot 128 (1998), 105-42.

MacGregor, G 1998a 'Archaeological work on the Fife Water Pipeline, 1995: the excavation of Bronze Age, Roman and medieval sites',
Tayside and Fife Archaeological Journal 4 (1988), 67-98.

MacGregor, G 1998b 'The excavation of a cordoned urn at Benderloch, Argyll', Proc Soc Antiq Scot 128 (1998), 143-59.

Mapleton, R J 1881 'Notice of the examination of a cist, on the banks of the River Add, at Crinan, Argyllshire', Proc Soc Antiq Scot, 15 (1880-1), 103-04.

Marshall, D N and Taylor, I D 1977 'The Excavation of the Chambered Cairn at Glenvoidean, Isle of Bute', Proc Soc Antiq Scot 108 (1976-77), 1-39.

Mercer, R J and Rideout, J 1987 'The excavation of a cist-group at Upper Largie quarry, Kilmartin, central Argyll 1982-1983', Glasgow Archaeol J 14 (1987), 25-38.

Miller, J J Ramsay, S and Housley, R A forthcoming 'Two thousand years of vegetation history and human impact within the Kilmartin Valley, Argyll, Scotland', Vegetation History and Archaeobotany.

RCAHMS 1999 Kilmartin Prehistoric \& Early Historic Monuments, An inventory of the monuments extracted from ARGYLL volume 6. Edinburgh.

Roberts, C and Manchester, K 1995 The Archaeology of Disease. (second edition). Stroud.

Roberts, J A 1998 'Cremated human remains', in MacGregor G 'The Excavation of a Cordoned Urn at Benderloch, Argyll', Proc Soc Antiq Scot 128 (1998), 143-59.

Roberts, J A 2000 Human Remains from Riff Cist, Orkney. [ = unpublished GUARD report on behalf of ARCUS].

Scott, J G 1991 'The Stone Circles at Temple Wood, Kilmartin, Argyll', Glasgow Archaeol J 15 (1988-89), 53-124.

Sheridan, A 2003 'New dates for Scottish Bronze Age cinerary urns: results from the National Museums of Scotland Dating Cremated Bones Project', in Gibson, A (ed.) Prehistoric Pottery People, pattern and purpose, 201-26. Oxford [ = Prehistoric Ceramics Research Group Occ Publ 4, British Archaeol Rep International Series 1156].

Shipman P, Foster, G and Schoeninger M 1984 'Burnt Bones and Teeth: an Experimental Study of Colour, Morphology, Crystal Structure and Shrinkage', Journal of Archaeological Science 11 (1984), 307-25.

Smith, R A 1873 'Descriptive List of Antiquities near Loch Etive, Argylleshire, consisting of Vitrified Forts, Cairns, Circles, Crannogs, etc.; 
with some Remarks on the Growth of Peat', Proc Soc Antiq Scot 9 (1870-72), 81-106.

Society of Antiquaries of Scotland 1865 'Donations to the Museum and Library [of the Society]', Proc Soc Antiq Scot 5 (1862-64), 81-84.

Society of Antiquaries of Scotland 1886 'Donations to the Museum and Library [of the Society]', Proc Soc Antiq Scot 20 (1885-86), 73-75.

Stevenson, J B 1997 'The Prehistoric Rock Carvings of Argyll', in Ritchie, G (ed.) The Archaeology of Argyll, 95-117. Edinburgh.
Stewart, M E C and Barclay, G 1997 'Excavations in burial and ceremonial sites of the Bronze Age in Tayside', Tayside Fife Archaeol $J 3$ (1997), 22-54.

Tolan-Smith, C 2001 The Caves of Mid Argyll; an archaeology of human use. Edinburgh. [ = Soc Antiq Scot Monograph 20].

Ubelaker, D H 1989 Human Skeletal Remains Excavation, Analysis, Interpretation (second edition). Washington DC. 


\section{Index}

Animal remains, cremated (sheep/goat) 9, 14

\section{Bronze Age burials}

animal remains accompanying human burials 14 cave sites used for funerary purposes 15

different ceramic traditions, lowlands and uplands 15

Bronze Age pottery Enlarged Food Vessel urn (aka Vase Urn) 7-8 problematic radiocarbon dates 13

Charcoal (birch, hazel, heather, oak, sloe-type) 12

\section{Cremation}

cremation process 10

pyre temperature 10
Glennan, Kilmartin

boulder shelter $3-6$

inverted urn 5-6, 7-8

pit for urn 5

radiocarbon dates 13

Human remains, cremated

age \& sex (adult male) 9

non-metric traits 9

pathology (spinal joint disease, iron deficiency anaemia) 9-10

urned cremation 5-6, 10

Lithics (flint flake) 11 